\title{
MARCUS MAGUS: \\ KULT, LEHRE UND GEMEINDELEBEN EINER \\ VALENTINIANISCHEN GNOSTIKERGRUPPE, SAMMLUNG DER QUELLEN UND KOMMENTAR'
}

\section{Niclas Förster}

The dissertation is the first study of the Valentinian Gnostic Mark the Magician. Despite the number and quality of sources, Mark, and his Valentinian doctrine and rites have been neglected in modern research, in contrast to his famous predecessors and contemporaries like Valentinus or Basilides, who have both been the subjects of monographs.

The thesis is divided into two main parts. The first collects and investigates the sources which mention Mark and his system of teaching. The second part provides a commentary on such writings.

The first part concludes that the work Adversus haereses written by Irenaeus against the heretics is the basis of our knowledge about Mark. Irenaeus himself drew on several sources for his report: he probably used and quoted, partly verbatim, a separate treatise in which Mark set down his teachings. The father of the Church also refers expressly to the missionary work done by 'pupils' of Mark in the river valley of the Rhône, i.e. in the immediate vicinity of Lyon, the seat of Irenaeus' bishopric. He further quotes from a Christian poem mocking the Gnostic. This fierce literary attack is unique in early Christian literature and was probably the main source which Irenaeus used for his polemic against Mark and his Gnostic adherents.

Another source besides Irenaeus is Hippolytus' treatise Refutatio omnium haeresium. Hippolytus based his own report on the older book by Irenaeus but added new information gathered in Marcosian circles in his own time. He even concedes that the Marcosians read and criticised Irenaeus' report on their religious rites.

1 Niclas Förster, Marcus Magus: Kult, Lehre und Gemeindeleben einer valentinianischen Gnostikergruppe, Sammlung der Quellen und Kommentar, Wissenschaftliche Untersuchungen zum Neuen Testament 114, Tübingen, Mohr Siebeck, 1999 (published version of doctoral dissertation, Georg-AugustUniversität, Göttingen, 1997); supervisor: Professor Dr Gerd Lüdemann. 
Further information is provided by an Arab world history, written by the Syrian bishop Agapius in the ninth century and including a short note about Mark's teaching. It is very likely that Agapius used certain writings of Irenaeus which are no longer extant.

The second part of the thesis deals with the Markosians' community-life, their cultic practice and the essential features of Mark's teaching. Adopting the form of a commentary this part turns its attention both to the report of Irenaeus and to the passages of Hippolytus and Agapius that provide additional information.

According to these reports, Mark carried out his missionary activity primarily in Asia Minor and probably between A.D. 160 and 180. He travelled around, visiting existing Christian communities and trying to convert their members to his own Gnostic ideas. That Mark taught in Asia Minor suggests that his teachings may have been closely linked to the ideas of other Gnostic groups distributed in the same area at approximately the same time. And in fact Irenaeus reports several points in Mark's teaching which are reminiscent of that of the Valentinian Gnostics. He also counted Mark among the 'pupils' of Valentinus. Apart from Valentinianism, which had a special significance within his Gnostic world-view, Mark assimilated a manifold and diverse body of thought: it can be assumed that he consciously regarded himself as Christian and referred to himself as one. His own teachings were shaped both by conventional Christian ideas and by his own interpretations of biblical texts. It was because of this that he made contact with Christian communities and tried to convert their congregations to his own brand of Gnostic theology. In this connection it is striking that, in contrast to other Valentinian teachers, Mark never referred to the Gospel of John. He also completely ignored Paul's Epistles. However, nothing precise can be established about the criteria determining his selection of New Testament texts because Irenaeus does not comment on them.

Mark's system of thought was based not only on Christian ideas but also entailed in a synthesis of ideas and arguments from various philosophical schools of the time. Above all Pythagorean speculations about certain numbers and letters were prominent in Mark's teaching, and his adoption of many central topics of Neo-Pythagorean treatises can be demonstrated in the excerpts of Irenaeus.

As in other Valentinian Gnostic systems traces of pagan myths can be detected in Mark's teachings. For example he adapted elements of Egyptian creation myths according to which the creator uttered words out of his mouth that caused him to materialise in bodily form and 
helped him to acquire self-knowledge. On top of that there was also the influence of popular religion, magic and numerology such as the allocation of a number to a proper name by gematria.

From our current perspective the Markosians occupy a most interesting place among the Valentinian groups, because Irenaeus' and Hippolytus' works contain information not only about Mark's doctrine but also about the cult and community-life of this Valentinian group. Their reports are valuable since they allow us to look at the form and sequence of the rites in the Gnostic service whereas in other Valentinian groups we possess only cultic formulae isolated from their Sitz im Leben. In the Markosian cult three rites must be distinguished.

(1) A rite of initiation set the seal on the introduction of new members to the Markosian group. During the course of the ceremony Mark himself or one of his adherents changed the colour of wine from white to red. For this he probablely used a non-toxic plant pigment. This rite expressed the Markosians' conviction that in the ceremony each 'pneumatic' human being could be united during his life time in a kind of spiritual marriage with his or her personal angel. The angel endowed the Gnostic with the gift of prophecy.

(2) A second special Markosian rite, in which a kind of effervescent powder was used to make a goblet of wine overflow, symbolised the initiate's increasing prophetic knowledge.

(3) After the death of each Gnostic, the union with the angel was supposed to manifest its worth by fortifying him or her to face the dangers of the world beyond. A special last rite, the so-called 'Apolytrosis', served as a means of securing the expected redemption.

With the help of its special rites and teachings Mark's circle could establish and stabilise itself within a Christian community. The Gnostics attended the Christian services and for some time were not perceived negatively. In addition to Christian ritual they practised their own separate cult, partly in the course of a common meal. Nevertheless, Mark and his adherents considered themselves to be Christians and led, so to speak, a double life, regarding themselves as a kind of Christian élite because of their Gnostic knowledge and prophetic ability.

The basis of their teachings was not a strictly logical connection of ideas, but rather a kind of associative network. Mark thought that because of his prophetic gift he could find hidden connections between the sometimes very different traditions which he adapted in his doctrine. His speculations about numbers and letters served the purpose of establishing such connections between elements of 
different traditions. For this reason he was able to interpret many parts of his system in two ways: on the one hand, he supported a traditional Christian meaning, and on the other hand maintained a second meaning, recognisable only by him, on the basis of Valentinian Gnosticism. This method of reading another meaning into aspects of the Christian faith, specially the biblical text, made his religious syncretism possible. In this way Mark and his adherents were able to describe themselves as Christians, but also to remain at the same time deeply committed to their basic pagan outlook without regarding this as syncretistic mixture of religion.

A very important influence also came from the mystery cults, especially the initiation rite described by Irenaeus. But why did Mark adapt such rites from these cults? The answer to this question must in many respects be hypothetical because the fathers of the church never mentioned any connection between these rites and those of the mystery cults. But Mark could have been motivated by the endeavour to understand and express ritually both the experience of the divine and the special status that could be attained in one's lifetime and would protect one even in the hereafter as a result of union therewith. 